\begin{tabular}{|c|l|}
\hline Title & $\begin{array}{l}\text { Room temperature borylation of arenes and heteroarenes using stoichiometric amounts of pinacol borane catalyzed by } \\
\text { iridium complexes in an inert solvent }\end{array}$ \\
\hline Author(s) & Ishiyama, Tatsuo; Nobuta, Y usuke; Hartwig, John F.; Miy aura, Norio \\
\hline Citation & $\begin{array}{l}\text { Chemical Communications, 23, 2924.2925 } \\
\text { https:/doi.org/10.1039/0311103b }\end{array}$ \\
\hline Issue Date & 2003 \\
\hline Doc URL & http://hdl.handle.net/2115/56377 \\
\hline Type & article (author version) \\
\hline File Information & (37) B-H + H-Ar (rt) (Com).pdf \\
\hline
\end{tabular}

Instructions for use 


\title{
Room temperature borylation of arenes and heteroarenes by stoichiometric amounts of pinacolborane catalyzed by iridium complexes in an inert solvent $\dagger$
}

\author{
Tatsuo Ishiyama, ${ }^{* a}$ Yusuke Nobuta, ${ }^{a}{ }^{\text {John F. Hartwig }}{ }^{b}$ and Norio Miyaura $*^{a}$ \\ ${ }^{a}$ Division of Molecular Chemistry, Graduate School of Engineering, Hokkaido University, Sapporo \\ 060-8628, Japan. Fax: +81-11-706-6562; Tel: +81-11-706-6562; E-mail: ishiyama@org- \\ mc.eng.hokudai.ac.jp \\ ${ }^{b}$ Department of Chemistry, Yale University, P.O. Box 208107, New Haven, Connecticut 06520-8107, \\ USA.
}

This submission was created using the RSC ChemComm Template (DO NOT DELETE THIS TEXT) (LINE INCLUDED FOR SPACING ONLY - DO NOT DELETE THIS TEXT)

\begin{abstract}
Aromatic C-H borylation of arenes and heteroarenes by stoichiometric amounts of pinacolborane was catalyzed by an iridium complex generated from $1 / 2[\operatorname{Ir}(\mathrm{OMe})(\mathrm{COD})]_{2}$ and 4,4'-di-tert-butyl-2,2'-bipyridine at room temperature in hexane and afforded the corresponding aryl- and heteroarylboronates in high yields with excellent regioselectivities.
\end{abstract}

Aryl- and heteroarylboron derivatives have been applied to various fields of chemistry. ${ }^{1}$ Traditional methods for their synthesis are based on the reactions of trialkylborates with arylmagnesium or -lithium reagents derived from haloarenes, which are most common and convenient for large-scale preparations. ${ }^{2}$ However, two milder catalytic methods have been developed recently. First, catalytic coupling of aryl and heteroaryl halides with tetra(alkoxo)diboron ${ }^{3}$ or di(alkoxo)borane ${ }^{4}$ reagents forms arylboronates without magnesium or lithium intermediates. Second, catalytic borylation of arenes and heteroarenes forms arylboronates without any halogenated arene.

Previous work has demonstrated the reaction of arenes and heteroarenes with bis(pinacolato)diboron $\left(\operatorname{pin}_{2} \mathrm{~B}_{2}\right.$, pin $=$ $\mathrm{Me}_{4} \mathrm{C}_{2} \mathrm{O}_{2}$ ) or pinacolborane (pinBH) in the presence of various transition metal complexes to form arylboronates. ${ }^{5-11}$ Most of these studies have been conducted with excess of substrate, and the resulting methods have required the use of $\operatorname{pin}_{2} B_{2}$ instead of pinBH to obtain high yields. No reactions of a $1: 1$ ratio of substrate and the readily accessible and inexpensive pinBH, instead of the expensive $\operatorname{pin}_{2} B_{2}$, have been reported. We disclose the culmination of several steps toward the development of such an aromatic $\mathrm{C}-\mathrm{H}$ borylation process. With modest loadings of $1 / 2[\operatorname{Ir}(\mathrm{OMe})(\mathrm{COD})]_{2}(\mathrm{COD}=1,5$-cyclooctadiene $)$ and 4,4'-ditert-butyl-2,2'-bipyridine (dtbpy), the reaction of pinBH with many arenes and heteroarenes in a 1:1 ratio occurs in an inert solvent at room temperature (Scheme 1).

$$
\begin{aligned}
& \operatorname{pinBH}+\underset{\mathrm{H}-\mathrm{Ar}}{\mathrm{H}} \frac{1 / 2[\mathrm{Ir}(\mathrm{OMe})(\mathrm{COD})]_{2} \text {-dtbpy }}{\text { hexane } / 25^{\circ} \mathrm{C}} \mathrm{pinB}-\mathrm{Ar}+\mathrm{H}_{2} \\
& \text { (1.1 eq.) }(1.0 \text { eq.) }
\end{aligned}
$$

To achieve the borylation of arenes and heteroarenes at room temperature with equimolar amounts of pinBH and substrate, several combinations of $\operatorname{Ir}(\mathrm{I})$ precursors $(0.03 \mathrm{mmol}$ of $\mathrm{Ir})$ and ligands $(0.03 \mathrm{mmol})$ were investigated as catalysts for the reaction of pinBH $(1.1 \mathrm{mmol})$ with 1,3-dichlorobenzene $(1.0$

$\dagger \quad$ Electronic Supplementary Information (ESI) available: experimental procedures and spectral analyses of products. See http://www.rsc.org/suppdata/cc/b0/b000000a/ $\mathrm{mmol})$ in hexane $(6 \mathrm{~mL})$ at $25{ }^{\circ} \mathrm{C}$ for $8 \mathrm{~h}$. Of the precursors and ligands examined, the combination of $1 / 2[\operatorname{Ir}(\mathrm{OMe})(\mathrm{COD})]_{2}$ and $\mathrm{dtbpy}^{12}$ efficiently catalyzed the borylation to form isomerically pure 5-boryl-1,3-dichlorobenzene in $86 \%$ yield.

The choice of catalyst precursor was crucial to observe room temperature reactions. Although the combination of $1 / 2[\operatorname{Ir}(\mathrm{OAc})(\mathrm{COD})]_{2}$ and dtbpy produced the borylated product in $42 \%$ yield after $8 \mathrm{~h}$, the combination of dtbpy and either $1 / 2[\operatorname{IrCl}(\mathrm{COD})]_{2}$ or $\left[\operatorname{Ir}(\mathrm{COD})_{2}\right] \mathrm{BF}_{4}$ formed no borylated product.

The effects of steric and electronic properties of bipyridine ligands were evaluated with $1 / 2[\operatorname{Ir}(\mathrm{OMe})(\mathrm{COD})]_{2}$ as a catalyst precursor. Catalysts bearing 2,2'-bipyridine (bpy), 4,4'-di-Mebpy, and 5,5'-di-Me-bpy displayed moderate or good reactivity, but catalysts bearing 3,3'-di-Me-bpy or 6,6'-di-Me-bpy displayed little activity. These results indicated the importance of a parallel arrangement of two pyridine rings and a relatively unhindered coordination sphere at iridium. Reactions catalyzed by complexes containing electron-rich derivatives of bpy generated more active catalysts than those containing electronpoor derivatives. Catalysts containing 4,4'-di- $\mathrm{Me}_{2} \mathrm{~N}-b p y$ produced the highest yields $(88 \%)$. We evaluated reactions catalyzed by $1 / 2[\operatorname{Ir}(\mathrm{OMe})(\mathrm{COD})]_{2}$ and dtbpy for studies on reaction scope because of the high solubility of the catalyst and the commercial availability of the ligand.

Proper choice of inert solvent was also important to observe efficient borylation. The reactions were faster in non-polar solvents, such as hexane, than in more polar and coordinating solvents. The order of reactivity in different solvents was hexane $>$ mesitylene $>$ DME $>$ DMF.

Reactions of equimolar amounts of pinBH with arenes and heteroarenes catalyzed by the combination of $1 / 2[\operatorname{Ir}(\mathrm{OMe})(\mathrm{COD})]_{2}$ and dtbpy at room temperature in hexane are summarized in Table 1. In contrast to the control of regioselectivity of electrophilic and nucleophilic substitution of arene by the electronic properties of substituents, the regiochemistry of $\mathrm{C}-\mathrm{H}$ borylation of arene is primarily controlled by the steric effects of these substituents. Reactions occurred at $\mathrm{C}-\mathrm{H}$ bonds located meta or para to a substituent in preference to those located ortho. Thus, 1,2- 1,4-, and 1,3-dichlorobenzenes gave a single product (Entries 1-3), but the 1,4-isomer reacted slowly (Entry 2). In addition, the borylation of 1,3-disubstituted arenes containing two different substituents at the 1 and 3 positions produced isomerically pure arylboronates in excellent yields. (Entries 4-9). In the case of five-membered heteroarenes, the electronegative heteroatom causes the $\mathrm{C}-\mathrm{H}$ bonds at the $\alpha$ positions to be active ${ }^{13}$ so that the borylation of indole, benzo $[b]$ furan, and benzo $[b]$ thiophene selectively occurred at the $\alpha$-positions to form single isomers in high yields (Entries 10-12).

Functional group tolerance of the borylation is higher than that of boronate syntheses through magnesium or lithium reagents. The reaction occurred with substrates possessing $\mathrm{Cl}, \mathrm{Br}$, $\mathrm{I}, \mathrm{CF}_{3}$, and $\mathrm{OMe}$ groups, but also the more reactive $\mathrm{CO}_{2} \mathrm{Me}$ and 
Table $1 \mathrm{C}-\mathrm{H}$ borylation of arenes and heteroarenes ${ }^{a}$

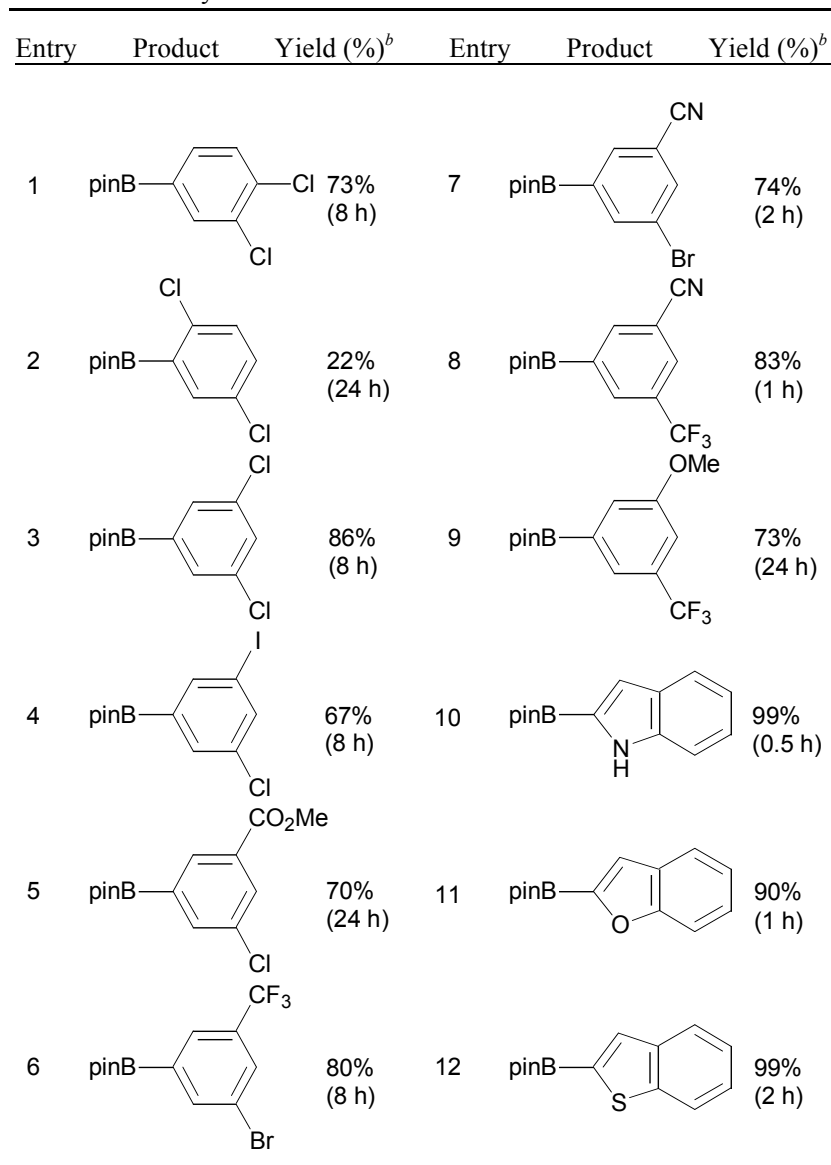

${ }^{a}$ All reactions were carried out at $25^{\circ} \mathrm{C}$ with pinacolborane $(1.1 \mathrm{mmol})$, arene or heteroarene $(1.0 \mathrm{mmol}),[\mathrm{Ir}(\mathrm{OMe})(\mathrm{COD})]_{2}(0.015 \mathrm{mmol}), \mathrm{dtbpy}$ $(0.03 \mathrm{mmol})$, and hexane $(6 \mathrm{~mL}) .{ }^{b} \mathrm{GC}$ yields based on arenes or heteroarenes and reaction times are in parentheses.

$\mathrm{CN}$. The aryl iodide and bromide underwent borylation at the C$\mathrm{H}$ bond (Entries 4, 6, and 7) without carbon-halogen bond cleavage ${ }^{14}$ Electron-withdrawing substituents activated the arene for the borylation process.

The mechanism of the catalytic borylation of arenes and heteroarenes by pinBH may proceed through an $\operatorname{Ir}(\mathrm{III})-\operatorname{Ir}(\mathrm{V})$ cycle. ${ }^{10-12,15}$ Generation of a (pinB) $)_{3} \operatorname{Ir}(\mathrm{III})$ intermediate ${ }^{10,11 \text { a, } 16}$ by the reaction of an $\operatorname{Ir}(\mathrm{I})$ complex with pinBH, oxidative addition of a $\mathrm{C}-\mathrm{H}$ bond to the (pinB $)_{3} \operatorname{Ir}(\mathrm{III})$ intermediate to yield an $(\mathrm{Ar})(\mathrm{H})(\mathrm{pinB})_{3} \operatorname{Ir}(\mathrm{V})$ species, and reductive elimination of pinB$\mathrm{Ar}$ from the $(\mathrm{Ar})(\mathrm{H})(\mathrm{pinB})_{3} \operatorname{Ir}(\mathrm{V})$ species to give a $(\mathrm{H})(\mathrm{pinB})_{2} \operatorname{Ir}(\mathrm{III})$ complex would be followed by oxidative addition of pinBH and reductive elimination of $\mathrm{H}_{2}$ to regenerate the $(\mathrm{pinB})_{3} \operatorname{Ir}(\mathrm{III})$ intermediate.

The direct preparation of aryl- and heteroarylboronates from pinBH and the corresponding arenes or heteroarenes creates an efficient, one-pot, two-step procedure for the synthesis of unsymmetrical biaryls. The biaryl shown in Scheme 2 was produced in $91 \%$ yield by sequential generation of 5-boryl-1,3dichlorobenzene from pinBH $(1.43 \mathrm{mmol})$ and $1,3-$ dichlorobenzene $(1.3 \mathrm{mmol})$ in hexane $(2 \mathrm{~mL})$, followed by reaction of the resulting arylboronate with added methyl 4bromobenzoate $(1.0 \mathrm{mmol}), \mathrm{PdCl}_{2}(\mathrm{dppf})(0.03 \mathrm{mmol}), \mathrm{K}_{3} \mathrm{PO}_{4}$ (3.0 mmol), and DMF $(4 \mathrm{~mL})$ at $60^{\circ} \mathrm{C} .{ }^{17}$

In summary, aromatic $\mathrm{C}-\mathrm{H}$ borylation of arenes and heteroarenes by pinBH without excess of substrate or reagent provides a convenient, economical, and environmentally benign route to regiodefined aryl- and heteroarylboronates. Further investigations to survey the scope and limitation of this $\mathrm{C}-\mathrm{H}$ borylation, including that of monosubstituted arenes, other heteroarenes, alkenes, and alkanes, as well as the application of

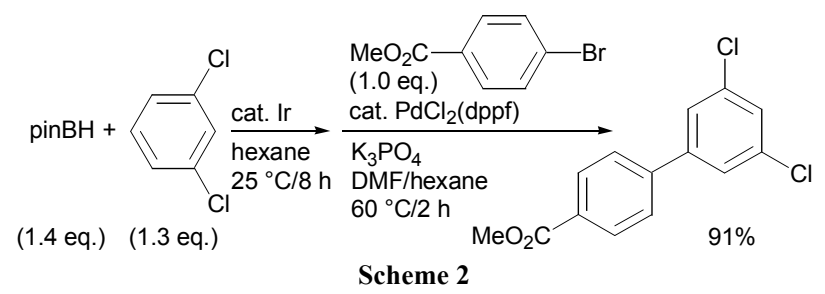

this catalyst system to other types of $\mathrm{C}-\mathrm{H}$ functionalizations are in progress.

This work was partially supported by Grant-in-Aid for Scientific Research on Priority Areas (No. 14078101, "Reaction Control of Dynamic Complexes") from Ministry of Education, Culture, Sports, Science and Technology, Japan and by the National Science Foundation (JFH). T.I. thanks Itoh Science Foundation and The Akiyama Foundation for support of a part of his work.

\section{Notes and references}

1 (a) M. Vaultier and B. Carboni in Comprehensive Organometallic Chemistry II, ed. E. W. Abel, F. G. A. Stone and G. Wilkinson, Pergamon Press, Oxford, 1995, vol. 11, p. 191; (b) K. Ishihara and H. Yamamoto, Eur. J. Org. Chem., 1999, 527; (c) S. Shinkai, M. Ikeda, A. Sugasaki and M. Takeuchi, Acc. Chem. Res., 2001, 34, 494; (d) C. D. Entwistle and T. B. Marder, Angew. Chem. Int. Ed., 2002, 41, 2927; (e) A. H. Soloway, W. Tjarks, B. A. Barnum, F.-G. Rong, R. F. Barth, I. M. Codogni and J. G. Wilson, Chem. Rev., 1998, 98, 1515; (f) W. Yang, X. Gao and B. Wang, Med. Res. Rev., 2003, 23, 346 .

2 A. N. Nesmeyanov and R. A. Sokolik, Methods of ElementoOrganic Chemistry, North-Holland, Amsterdam, 1967, vol. 1.

3 (a) T. Ishiyama and N. Miyaura, J. Synth. Org. Chem., Jpn., 1999, 57, 503; (b) T. Ishiyama and N. Miyaura, J. Organomet. Chem., 2000, 611, 392.

4 M. Murata, T. Oyama, S. Watanabe and Y. Masuda, J. Org. Chem., 2000, 65, 164

5 A review, see: T. Ishiyama and N. Miyaura, J. Organomet. Chem., 2003, 680, 3.

6 C. N. Iverson and M. R. Smith, III, J. Am. Chem. Soc., 1999, 121, 7696.

7 H. Chen and J. F. Hartwig, Angew. Chem. Int. Ed., 1999, 38, 3391.

8 (a) H. Chen, S. Schlecht, T. C. Semple and J. F. Hartwig, Science, 2000, 287, 1995; (b) J.-Y. Cho, C. N. Iverson and M. R. Smith, III, J. Am. Chem. Soc., 2000, 122, 12868; (c) M. K. Tse, J.-Y. Cho and M. R. Smith, III, Org. Lett., 2001, 3, 2831.

9 S. Shimada, A. S. Batsanov, J. A. K. Howard and T. B. Marder, Angew. Chem. Int. Ed., 2001, 40, 2168.

10 J.-Y. Cho, M. K. Tse, D. Holmes, R. E. Maleczka, Jr. and M. R. Smith, III, Science, 2002, 295, 305.

11 (a) T. Ishiyama, J. Takagi, K. Ishida, N. Miyaura, N. R. Anastasi and J. F. Hartwig, J. Am. Chem. Soc., 2002, 124, 390; (b) J. Takagi, K. Sato, J. F. Hartwig, T. Ishiyama and N. Miyaura, Tetrahedron Lett., 2002, 43, 5649.

12 T. Ishiyama, J. Takagi, J. F. Hartwig and N. Miyaura, Angew. Chem. Int. Ed., 2002, 41, 3056.

13 (a) L. Dong, S. B. Duckett, K. F. Ohman and W. D. Jones, J. Am. Chem. Soc., 1992, 114, 151; (b) T. Morikita, M. Hirano, A. Sasaki and S. Komiya, Inorg. Chim. Acta, 1999, 291, 341; (c) S. N. Ringelberg, A. Meetsma, B. Hessen and J. H. Teuben, J. Am Chem. Soc., 1999, 121, 6082.

14 J. D. Atwood in Comprehensive Organometallic Chemistry II, ed. E. W. Abel, F. G. A. Stone and G. Wilkinson, Pergamon Press, Oxford, 1995, vol. 8, p. 303.

15 Theoretical studies, see: H. Yamazaki, H. Tamura, M. Sugimoto, H. Sato and S. Sakaki, 49th Symposium on Organometallic Chemistry, Japan, 2002, PA119.

16 P. Nguyen, H. P. Blom, S. A. Westcott, N. J. Taylor and T. B. Marder, J. Am. Chem. Soc., 1993, 115, 9329.

17 (a) N. Miyaura and A. Suzuki, Chem. Rev., 1995, 95, 2457; (b) N. Miyaura, Top. Curr. Chem., 2002, 219, 11; (c) A. Suzuki and H. C. Brown, Organic Syntheses Via Boranes, Aldrich Chemical Company, Inc., Milwaukee, 2003, vol. 3. 


\title{
Room temperature borylation of arenes and heteroarenes by stoichiometric amounts of pinacolborane catalyzed by iridium complexes in an inert solvent
}

Tatsuo Ishiyama,* Yusuke Nobuta and Norio Miyaura*

\author{
Division of Molecular Chemistry, Graduate School of Engineering, Hokkaido \\ University, Sapporo 060-8628, Japan
}

John F. Hartwig
Department of Chemistry, Yale University, P.O. Box 208107, New Haven, Connecticut 06520-8107, USA

\section{Electronic Supplementary Information (ESI)}

General Methods. All the experiments were carried out under a nitrogen atmosphere. ${ }^{1} \mathrm{H}$ and ${ }^{13} \mathrm{C}$ NMR spectra were recorded in $\mathrm{CDCl}_{3}$ solutions using a JEOL JNM-A400II spectrometer (400 or 100 $\mathrm{MHz}$ ) and $\mathrm{Me}_{4} \mathrm{Si}$ or residual protiated solvent as an internal standard. High-resolution mass spectra were obtained on a JEOL JMS-DX303. GC analyses were performed on a Hitachi G-3500 instrument equipped with a glass column (OV-101 on Uniport B, 2 m). Solvents, arenes, and hetroarenes were purified by distillation from appropriate drying agents. Pinacolborane was prepared by Knochel's method ${ }^{1}$ and purified by distillation through a Widmer column. $[\operatorname{Ir}(\mathrm{OMe})(\mathrm{COD})]_{2},{ }^{2}[\operatorname{Ir}(\mathrm{OAc})(\mathrm{COD})]_{2},{ }^{3} 4,4^{\prime}$-bis $(N, N$ dimethylamino)-2,2'-bipyridine, ${ }^{4}$ 4,4'-dimethoxy-2,2'-bipyridine, ${ }^{4} 4,4$ '-dichloro-2,2'-bipyridine, ${ }^{4}$ and 4,4'-dinitro-2,2'-bipyridine ${ }^{5}$ were synthesized by the reported procedures. All of other compounds were used as received.

General Procedure for Aromatic C-H Borylation by Pinacolborane (Table 1). A 25-mL flask assembled a magnetic stirring bar, a septum inlet, a condenser, and a bubbler was charged with $[\operatorname{Ir}(\mathrm{OMe})(\mathrm{COD})]_{2}(0.015 \mathrm{mmol})$ and 4,4'-di-tert-butyl-2,2'-bipyridine (0.03 mmol), and then flushed with nitrogen. Dry hexane $(6 \mathrm{~mL})$, pinacolborane $(1.1 \mathrm{mmol})$, and an arene or a heteroarene $(1.0 \mathrm{mmol})$ were added, and the mixture was stirred at $25{ }^{\circ} \mathrm{C}$ for the period shown in Table 1 . The reaction mixture was 
treated with water at room temperature, extracted with benzene, washed with brine, and dried over $\mathrm{MgSO}_{4}$. Kugelrohr distillation in vacuo gave an analytically pure sample.

1,2-Dichloro-4-(4,4,5,5-tetramethyl-1,3,2-dioxaborolan-2-yl)benzene (Entry 1). The purity determined by NMR and GC analyses: > 95\%; ${ }^{1} \mathrm{H}$ NMR $\delta 1.34$ (s, $\left.12 \mathrm{H}\right), 7.44(\mathrm{~d}, 1 \mathrm{H}, J=7.8 \mathrm{~Hz}), 7.60$ $(\mathrm{d}, 1 \mathrm{H}, J=8.1 \mathrm{~Hz}), 7.87(\mathrm{~s}, 1 \mathrm{H}) ;{ }^{13} \mathrm{C}$ NMR $\delta 24.82,84.31,129.98,132.23,133.73,135.46,136.53$; exact mass calcd for $\mathrm{C}_{12} \mathrm{H}_{15} \mathrm{BCl}_{2} \mathrm{O}_{2} 272.0542$, found 272.0534 .

1,4-Dichloro-2-(4,4,5,5-tetramethyl-1,3,2-dioxaborolan-2-yl)benzene (Entry 2). The purity determined by NMR and GC analyses: $>95 \% ;{ }^{1} \mathrm{H}$ NMR $\delta 1.37$ (s, $\left.12 \mathrm{H}\right), 7.27(\mathrm{~d}, 1 \mathrm{H}, J=8.1 \mathrm{~Hz}), 7.30$ $(\mathrm{dd}, 1 \mathrm{H}, J=8.5$ and $2.2 \mathrm{~Hz}), 7.65(\mathrm{~d}, 1 \mathrm{H}, J=2.0 \mathrm{~Hz}) ;{ }^{13} \mathrm{C} \mathrm{NMR} \delta 24.75,84.46,130.68,131.69,132.08$, 136.02, 137.7; exact mass calcd for $\mathrm{C}_{12} \mathrm{H}_{15} \mathrm{BCl}_{2} \mathrm{O}_{2}$ 272.0542, found 272.0549.

1,3-Dichloro-5-(4,4,5,5-tetramethyl-1,3,2-dioxaborolan-2-yl)benzene (Entry 3). The purity determined by NMR and GC analyses: > 95\%; ${ }^{1} \mathrm{H}$ NMR $\delta 1.34(\mathrm{~s}, 12 \mathrm{H}), 7.43$ (t, $\left.1 \mathrm{H}, J=2.0 \mathrm{~Hz}\right), 7.65$ (d, $2 \mathrm{H}, J=2.0 \mathrm{~Hz}) ;{ }^{13} \mathrm{C}$ NMR $\delta 24.81,84.48,131.05,132.67$, 134.69; exact mass calcd for $\mathrm{C}_{12} \mathrm{H}_{15} \mathrm{BCl}_{2} \mathrm{O}_{2}$ 272.0542 , found 272.0566 .

1-Chloro-3-iodo-5-(4,4,5,5-tetramethyl-1,3,2-dioxaborolan-2-yl)benzene (Entry 4). The purity determined by NMR and GC analyses: > 95\%; ${ }^{1} \mathrm{H}$ NMR $\delta 1.34$ (s, $\left.12 \mathrm{H}\right), 7.72(\mathrm{~d}, 1 \mathrm{H}, J=1.5 \mathrm{~Hz})$, $7.78(\mathrm{t}, 1 \mathrm{H}, J=1.2 \mathrm{~Hz}), 8.00$ (s, $1 \mathrm{H}) ;{ }^{13} \mathrm{C} \mathrm{NMR} \delta 24.81,84.46,94.18,133.71,134.70,139.42,141.42$; exact mass calcd for $\mathrm{C}_{12} \mathrm{H}_{15} \mathrm{BClIO}_{2} 363.9899$, found 363.9880 .

Methyl 3-chloro-5-(4,4,5,5-tetramethyl-1,3,2-dioxaborolan-2-yl)benzoate (Entry 5). The purity determined by NMR and GC analyses: > 95\%; ${ }^{1} \mathrm{H}$ NMR $\delta 1.35$ (s, $\left.12 \mathrm{H}\right), 3.92(\mathrm{~s}, 3 \mathrm{H}), 7.95(\mathrm{~d}, 1 \mathrm{H}$, $J=1.5 \mathrm{~Hz}), 8.09$ (t, $1 \mathrm{H}, J=1.2 \mathrm{~Hz}), 8.33(\mathrm{~s}, 1 \mathrm{H}) ;{ }^{13} \mathrm{C}$ NMR $\delta 24.82,52.30,84.42,131.32,132.10$, 133.70, 134.28, 138.79, 165.93; exact mass calcd for $\mathrm{C}_{14} \mathrm{H}_{18} \mathrm{BClO}_{4} 296.0987$, found 296.0993.

3-Bromo-5-(4,4,5,5-tetramethyl-1,3,2-dioxaborolan-2-yl)benzotrifluoride (Entry 6). The purity determined by NMR and GC analyses: > 95\%; ${ }^{1} \mathrm{H}$ NMR $\delta 1.36$ (s, $\left.12 \mathrm{H}\right), 7.83$ (s, $\left.1 \mathrm{H},\right), 7.97$ (s, 1 $\mathrm{H}), 8.10(\mathrm{~s}, 1 \mathrm{H}) ;{ }^{13} \mathrm{C}$ NMR $\delta$ 24.82, 84.66, $122.49,123.26$ (q, $\left.J=272.9 \mathrm{~Hz}\right), 129.83(\mathrm{q}, J=3.3 \mathrm{~Hz})$, $130.80(\mathrm{q}, J=4.1 \mathrm{~Hz}), 131.88(\mathrm{q}, J=32.8 \mathrm{~Hz}), 140.82$; exact mass calcd for $\mathrm{C}_{13} \mathrm{H}_{15} \mathrm{BBrF}_{3} \mathrm{O}_{2} 350.0300$, found 350.0309 .

3-Bromo-5-(4,4,5,5-tetramethyl-1,3,2-dioxaborolan-2-yl)benzonitrile (Entry 7). The purity determined by NMR and GC analyses: $>95 \% ;{ }^{1} \mathrm{H}$ NMR $\delta 1.35(\mathrm{~s}, 12 \mathrm{H}), 7.85(\mathrm{~s}, 1 \mathrm{H}), 8.01(\mathrm{~s}, 1 \mathrm{H}), 8.13$ $(\mathrm{s}, 1 \mathrm{H}) ;{ }^{13} \mathrm{C}$ NMR $\delta 24.81,84.85,113.77,117.32,122.60,136.70,136.74,141.73$; exact mass calcd for $\mathrm{C}_{13} \mathrm{H}_{15} \mathrm{BBrNO}_{2}$ 307.0379, found 307.0387.

3-Trifluoromethyl-5-(4,4,5,5-tetramethyl-1,3,2-dioxaborolan-2-yl)benzonitrile (Entry 8). The purity determined by NMR and GC analyses: $>95 \% ;{ }^{1} \mathrm{H}$ NMR $\delta 1.37$ (s, $\left.12 \mathrm{H}\right), 7.98$ (s, $\left.1 \mathrm{H}\right), 8.26$ (s, $2 \mathrm{H}) ;{ }^{13} \mathrm{C}$ NMR $\delta 24.81,85.03,112.96,117.39,123.02$ (q, $\left.J=272.6 \mathrm{~Hz}\right), 131.01$ (q, $\left.J=4.1 \mathrm{~Hz}\right), 131.30$ 
$(\mathrm{q}, J=33.6 \mathrm{~Hz}), 135.22(\mathrm{q}, J=3.3 \mathrm{~Hz}), 141.33$; exact mass calcd for $\mathrm{C}_{14} \mathrm{H}_{15} \mathrm{BF}_{3} \mathrm{NO}_{2} 297.1148$, found 297.1153.

3-Trifluoromethyl-5-(4,4,5,5-tetramethyl-1,3,2-dioxaborolan-2-yl)anisole (Entry 9). The purity determined by NMR and GC analyses: > 95\%; ${ }^{1} \mathrm{H}$ NMR $\delta 1.35$ (s, $\left.12 \mathrm{H}\right), 3.86(\mathrm{~s}, 3 \mathrm{H}), 7.21$ (s, 1 H), $7.48(\mathrm{~d}, 1 \mathrm{H}, J=2.2 \mathrm{~Hz}), 7.65(\mathrm{~s}, 1 \mathrm{H}) ;{ }^{13} \mathrm{C}$ NMR $\delta 24.81,55.52,84.29,114.10$ (q, $\left.J=3.3 \mathrm{~Hz}\right)$, 122.50, 123.43 (q, $J=3.3 \mathrm{~Hz}), 124.01$ (q, $J=272.6 \mathrm{~Hz}), 131.34$ (q, $J=32.0 \mathrm{~Hz}), 159.16$; exact mass calcd for $\mathrm{C}_{14} \mathrm{H}_{18} \mathrm{BF}_{3} \mathrm{O}_{3} 302.1301$, found 302.1314 .

2-(4,4,5,5-Tetramethyl-1,3,2-dioxaborolan-2-yl)indole (Entry 10). The purity determined by NMR and GC analyses: $>95 \% ;{ }^{1} \mathrm{H}$ NMR $\delta 1.36(\mathrm{~s}, 12 \mathrm{H}), 7.09$ (t, $\left.1 \mathrm{H}, J=7.7 \mathrm{~Hz}\right), 7.11$ (s, $\left.1 \mathrm{H}\right), 7.23$ (t, $1 \mathrm{H}, J=8.3 \mathrm{~Hz}), 7.38(\mathrm{~d}, 1 \mathrm{H}, J=8.3 \mathrm{~Hz}), 7.67(\mathrm{~d}, 1 \mathrm{H}, J=7.8 \mathrm{~Hz}), 8.56$ (br s, $1 \mathrm{H}) ;{ }^{13} \mathrm{C} \mathrm{NMR} \delta 24.78$, $84.13,111.25,113.83,119.75,121.57,123.59,128.24,138.18$; exact mass calcd for $\mathrm{C}_{14} \mathrm{H}_{18} \mathrm{BNO}_{2}$ 243.1431 , found 243.1433 .

2-(4,4,5,5-Tetramethyl-1,3,2-dioxaborolan-2-yl)benzo[b]furan (Entry 11). The purity determined by NMR and GC analyses: $>95 \%$; ${ }^{1} \mathrm{H}$ NMR $\delta 1.39(\mathrm{~s}, 12 \mathrm{H}), 7.23$ (t, $\left.1 \mathrm{H}, J=7.4 \mathrm{~Hz}\right), 7.34$ $(\mathrm{dt}, 1 \mathrm{H}, J=1.2$ and $7.8 \mathrm{~Hz}), 7.40(\mathrm{~s}, 1 \mathrm{H}), 7.57(\mathrm{~d}, 1 \mathrm{H}, J=8.5 \mathrm{~Hz}), 7.63(\mathrm{~d}, 1 \mathrm{H}, J=7.8 \mathrm{~Hz}) ;{ }^{13} \mathrm{C}$ NMR $\delta$ $24.73,84.64,111.92,119.50,121.84,122.68,125.89$, 127.43, 157.45; exact mass calcd for $\mathrm{C}_{14} \mathrm{H}_{17} \mathrm{BO}_{3}$ 244.1271 , found 244.1278 .

2-(4,4,5,5-Tetramethyl-1,3,2-dioxaborolan-2-yl)benzo [b]thiophene (Entry 12). The purity determined by NMR and GC analyses: $>95 \% ;{ }^{1} \mathrm{H}$ NMR $\delta 1.38(\mathrm{~s}, 12 \mathrm{H}), 7.35(\mathrm{ddd}, 1 \mathrm{H}, J=1.7,7.3$, and $8.8 \mathrm{~Hz}$ ), 7.37 (ddd, $1 \mathrm{H}, J=1.8,7.1$, and $9.0 \mathrm{~Hz}$ ), 7.85 (dd, $1 \mathrm{H}, J=2.2$ and $9.0 \mathrm{~Hz}), 7.89$ (s, $1 \mathrm{H}), 7.91$ (dd, $1 \mathrm{H}, J=1.5$ and $9.0 \mathrm{~Hz}) ;{ }^{13} \mathrm{C}$ NMR $\delta 24.79,84.42,122.50,124.08,124.35,125.29,134.47,140.41$, 143.67; exact mass calcd for $\mathrm{C}_{14} \mathrm{H}_{17} \mathrm{BO}_{2} \mathrm{~S} 260.1042$, found 260.1019.

\section{One-Pot Synthesis of methyl 4-(3,5-dichlorophenyl)benzoate via Borylation-Coupling}

Sequence (Scheme 2). To a solution of 1,3-dichloro-5-(4,4,5,5-tetramethyl-1,3,2-dioxaborolan-2yl)benzene resulted by the reaction of pinacolborane $(1.43 \mathrm{mmol})$ with 1,3 -dichlorobenzene $(1.3 \mathrm{mmol})$ in dry hexane $(2 \mathrm{~mL})$ were added methyl 4-bromobenzoate $(1.0 \mathrm{mmol}), \mathrm{PdCl}_{2}(\mathrm{dppf})(0.03 \mathrm{mmol}), \mathrm{K}_{3} \mathrm{PO}_{4}$ (3.0 mmol), and DMF ( $4 \mathrm{~mL})$, and the mixture was stirred at $60{ }^{\circ} \mathrm{C}$ for $1 \mathrm{~h}$. The product was extracted with benzene, washed with water, and dried over $\mathrm{MgSO}_{4}$. Column chromatography over silica gel provided analytically pure methyl 4-(3,5-dichlorophenyl)benzoate: The purity determined by NMR and GC analyses: > 95\%; ${ }^{1} \mathrm{H}$ NMR $\delta 3.95$ (s, $\left.3 \mathrm{H}\right), 7.39$ (t, $\left.1 \mathrm{H}, J=1.8 \mathrm{~Hz}\right), 7.49$ (d, $\left.2 \mathrm{H}, J=1.7 \mathrm{~Hz}\right), 7.61$ (dt, $2 \mathrm{H}, J=8.5$ and $1.8 \mathrm{~Hz}), 8.12(\mathrm{dt}, 2 \mathrm{H}, J=8.3$ and $1.7 \mathrm{~Hz}) ;{ }^{13} \mathrm{C} \mathrm{NMR} \delta 52.25,125.77,127.03,127.95$, $130.04,130.29,135.49,142.76,142.95,166.59$; exact mass calcd for $\mathrm{C}_{14} \mathrm{H}_{10} \mathrm{Cl}_{2} \mathrm{O}_{2} 280.0058$, found 280.0047. 


\section{References}

1. C. E. Tucker, J. Davidson and P. Knochel, J. Org. Chem., 1992, 57, 3482.

2. R. Uson, L. A. Oro and J. A. Cabeza, Inorg. Synth., 1985, 23, 126.

3. R. N. Haszeldine, R. J. Lunt and R. V. Parish, J. Chem. Soc. A, 1971, 3696.

4. P. Wehman, G. C. Dol, E. R. Moorman, P. C. J. Kamer, P. W. N. M. van Leeuwen, J. Fraanje and K. Goubitz, Organometallics, 1994, 13, 4856.

5. D. Wenkert and R. B. Woodward, J. Org. Chem., 1983, 48, 283. 
RSC Author Templates - ChemDraw (CDX) - Graphical Abstracts

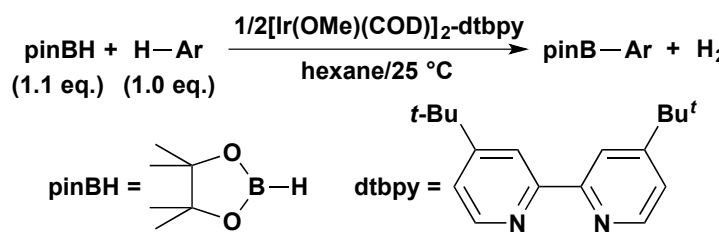

Aromatic $\mathrm{C}-\mathrm{H}$ borylation of arenes and heteroarenes by stoichiometric amounts of pinacolborane was catalyzed by an iridium complex generated from $1 / 2[\operatorname{Ir}(O M e)(C O D)]_{2}$ and 4,4'-di-tertbutyl-2,2'-bipyridine at room temperature in hexane, and afforded the corresponding aryl- and heteroarylboronates in high yields with excellent regioselectivities. 